\title{
A DATABASE OF HISTORICAL FLOOD EVENTS IN THE NETHERLANDS
}

\author{
Martine $\mathrm{Jak}^{1}$ and Matthijs $\mathrm{Kok}^{2}$ \\ ${ }^{1}$ Department of Transport, Public works and Water Management \\ Road and Hydraulic Engineering Division \\ P.O. Box 5044 \\ 2600 GA Delft \\ The Netherlands \\ e-mail:m.jak@dww.rws.minvenw.nl \\ ${ }^{2}$ HKV Consultants \\ P.O. Box 2120 \\ 8203 AC Lelystad \\ The Netherlands \\ e-mail:m.kok@hkv.nl
}

\section{Introduction}

The Netherlands is situated on the delta of three of Europe's main rivers: the Rhine, the Meuse and the Scheldt. As a result of this, the country has been able to develop into an important, densely populated nation. But living in the Netherlands is not without risks. Large parts of the Netherlands are below mean sea level and water levels which may occur on the rivers Rhine and Meuse. High water levels due to storm surges on the North Sea or due to high discharges of the rivers are a serious threat for the low lying part of the Netherlands. Construction, management and maintenance of flood defences are essential conditions for the population and further development of the country.

Without flood defences much of the Netherlands would be regularly flooded. The influence of the sea would be felt principally in the west. The influence of the waters of the major rivers is of more limited geographic impact. Along the coast, protection against flooding is principally provided by dunes. Where the dunes are absent or too narrow or where the sea arms have been closed off, flood defences in the form of sea dikes or storm surge barriers have been constructed. Along the full length of the Rhine and along the parts of the Meuse protection against flooding in provided by dikes.

Safety in the Netherlands is organized witin dike rings. A dike ring is an area which will be flooded if there is an extreme hydraulic load from the sea, the lake IJsselmeer or one of the big rivers. Figure 1 presents an overview of the 53 dike rings. 


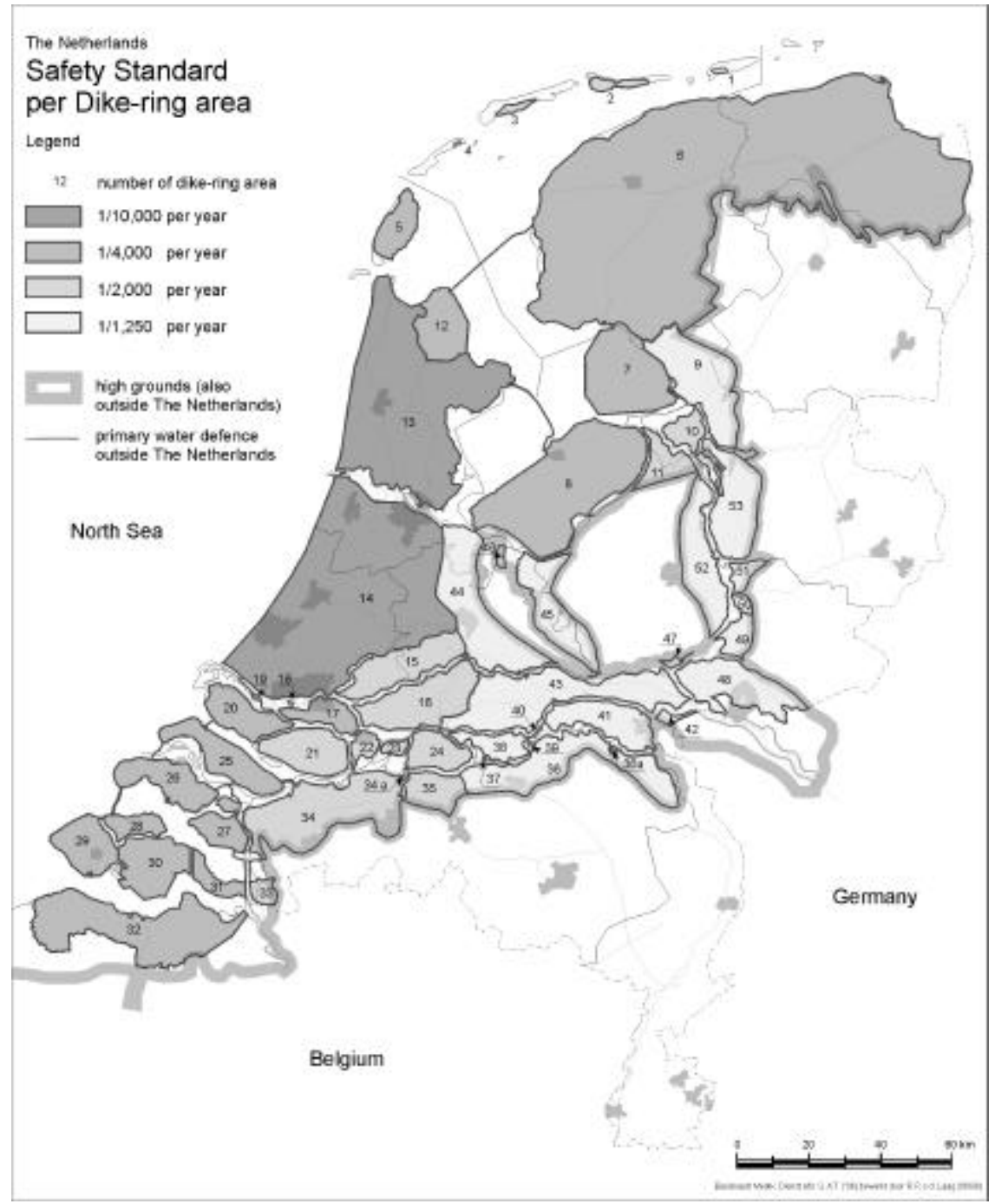

Figure 1. Dike rings in the Netherlands

In this paper we present the first results of the design of a central database with all relevant estimates of flooding events in the Netherlands. In the past 50 years five big flooding events happened. Because of the wide diversity of data a flexible database has been build. A major effort was to include the relevant data in the database. At the end of this paper we discuss the use of this approach for including flooding events outside the Netherlands in this database. 


\section{Flood management in the Netherlands}

The current safety standard was set after the big 1953 flood disaster in the Netherlands (see for example [1] and [2]). After this flood the design method of flood protection was improved considerably because of the scientific approach. This approach was invented by the Delta Commission [5] and [6]. The standard approach for designing flood protection structures used until then was based on the highest recorded water level. In relation to this water level a certain margin (of 0,5 to 1,0 meter) was maintained. The Delta commission recommended that a certain desired water level of safety be taken as starting point. The safety standards should be based on weighing the costs of the construction of flood protection structures and the possible damage caused by floods. An econometric analysis was undertaken by the Delta commission for Central Holland. Based on information from 1960 this led to an optimum policy of $8 * 10^{-6}$ per year. For practical design this was converted into a design water level with a frequency of exceedance of $10^{-4}$ per year. See figure 2 for the approach of the Delta Commission.

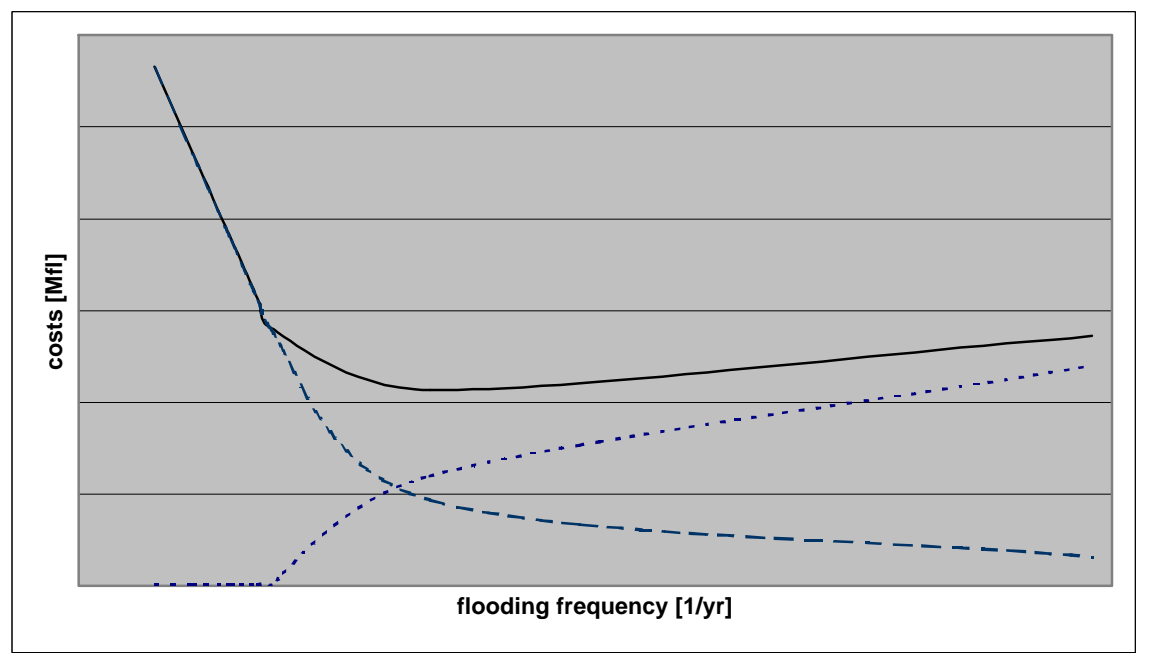

Figure 2. The optimal safety approach in economical terms. The total costs (straight line) is the sum of flood damage (dashed line) and costs of dike construction (dotted line).

The Delta commission was not able to implement the safety concept completely, because of limited available technical capabilities. Especially the probability of a flood protection structure collapsing, and therefore the probability of flooding was difficult to estimate. This is why a simplified safety concept was chosen at that time.

In the near future a risk - based flood protection policy is expected. At present the tools required for such a policy are being developed. In the risk-based concept the safety assessment of flood protection structures is replaced by a total risk assessment. It is evident that the probability of flooding is not the same as the probability of the design load being exceeded. 
Flooding of a dike ring causes enormous damage. The extent of this damage depends on the nature of the flood, for example sea water or fresh water) and the properties of the area, for example depth and land use. Escape possibilities and early evacuation can play a mitigating role here.

The concept of flooding risks also offer the possibility of introducing other measures than building dikes. The risk of flooding can for example be reduced by constructing vulnerable elements on relatively high grounds.

\section{Set-up of a flood-damage database}

A number of big flooding events happened in the Netherlands. The biggest flood happened in 1953 with almost 2000 victims. The five events include river floods and

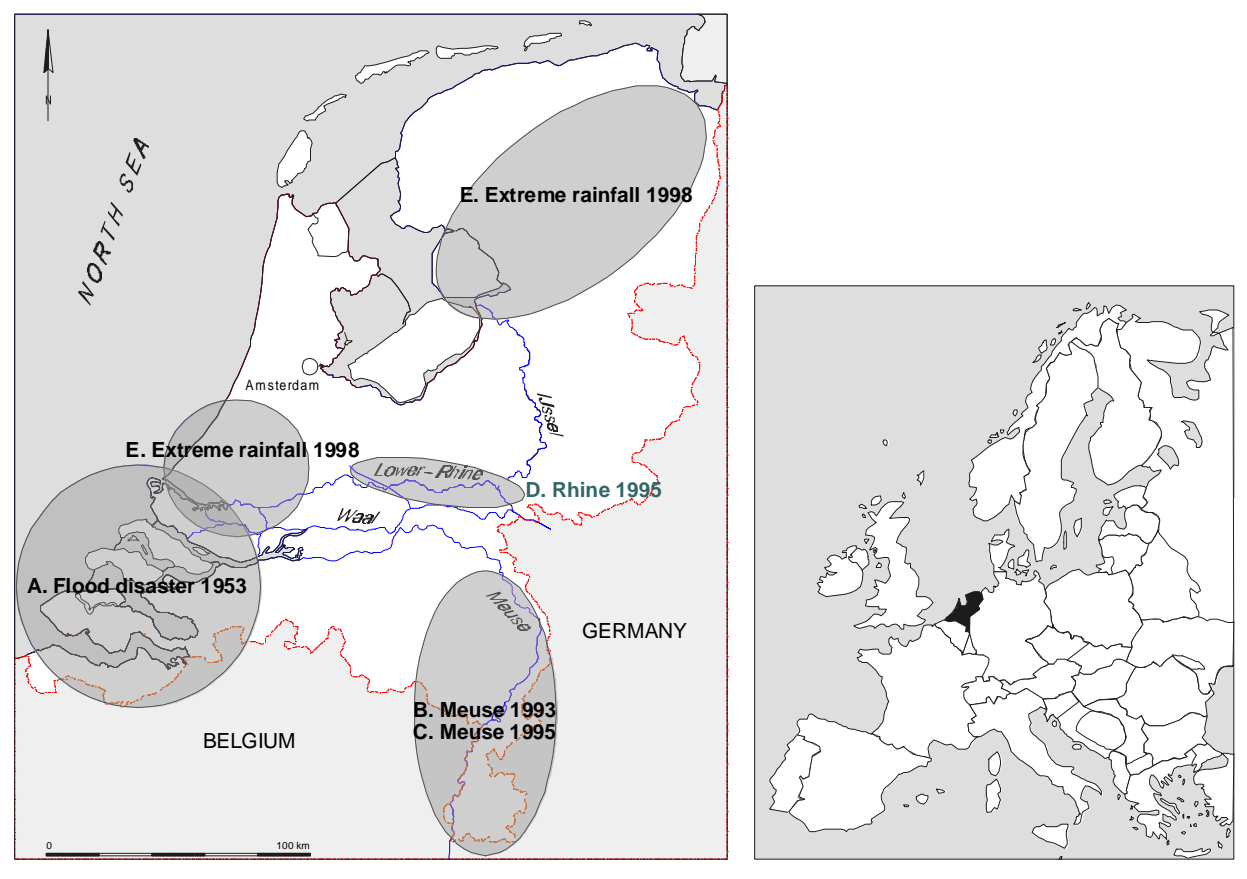

Figure 3. Flood events in the Netherlands

damage because of heavy rainfall in the Netherlands. Because the Netherlands is partly below sea level, heavy rainfall can cause a lot of damage because of limited pump capacity. An overview of the locations of the five events is given in figure 3.

The database is linked with a Geographic Information System, so that the geographical properties of the damage can be shown immediately (for example the hot spots van immediately identified). 


\section{Flood disaster in South West Holland in winter 1953}

The vulnerability of the Netherlands was made clear in the winter of 1953. A weather depression - combined with an exceptionally high spring tide - caused a storm surge on the North Sea, pushing water levels to record heights. Dikes failed in several places, especially in the south-western part of the country. In almost all cases, the dikes were too low, causing them to collapse. Overflow and wave overtopping led to large scale failures of the inner slope. The direct result of the disaster was 1835 victims and economic damage of NLG 1.5 billion (1956 price index). The indirect economic damage is estimated as a multiple of this. Flooding in Central Holland was barely avoided. The concentration of economic activities in this part of the country would have meant much greater damage.

In the database the number of victims and economic damage is given per polder. In the database a number of properties of these polders are also given. These properties include among others:

The damage and the number of victims was estimated by the National Office of Statistics.

\section{Flooding along the Meuse in December 1993}

Around Christmas 1993, the Dutch river Meuse flooded due to an extreme discharge of the river Meuse. Discharge larger than $3100 \mathrm{~m} 3 / \mathrm{s}$ have a probability of occurrence of about once in 150 years. In this part of the Netherlands there are no embankments or dikes. The river has a length of about 150 kilometers. The flood caused a damage of about 250 million Dutch guilders, a flooded area of about 18,000 hectares. About 8.000 people had to evacuate during several weeks [8].

The total damage can be divided into the following categories: houses (95 million guilders), agriculture (20 million guilders), companies (75 million guilders) and governmental buildings, schools, etc.: 60 million guilders). For each object the damage was estimated and inserted in the database.

The damage of all houses, industry, agriculture and the governmental buildings was estimated by damage-experts of the Dutch insurance companies.

\section{Flooding along the Meuse in January 1995}

A year after the Christmas flood in the South of the Netherlands, another event happened in the same area. The discharge at the border with Belgium was somewhat lower than in 1993, but in January 1995 the duration of the flooding was longer. The total damage in 1995 was 165 million guilders, which was considerably lower than in 1993. The explanation for this is that the people were in 1995 much prepared that floods were possible in their region than in 1993 [4].

The total damage can be divided into the following categories: houses (40 million guilders), agriculture (20 million guilders), companies (60 million guilders) and governmental buildings, schools, etc.: 45 million guilders). For each object the damage 
was estimated and inserted in the database. From these numbers it can be concluded that the main difference with the damage in 1993 is the damage in and around the houses. The damage of all houses, industry, agriculture and the governmental buildings was estimated by damage-experts of the Dutch insurance companies.

\section{Evacuation along the Rhine in January 1995}

In 1995 there were also problems around the river Rhine. In Germany, much damage occurred, and in the Netherlands there was a lot of emotion around the river dikes. The safety could not be guaranteed, and therefore some 200.000 people had to be evacuated for more than one week. Fortunately, there was no dike failure, so we could not collect the damage of the flooding of this event. However, the evacuation caused a lot of costs, and it would be very helpful to have a rough estimation of these costs.

The costs of all companies are estimated by damage-experts of the Dutch insurance companies, and these costs were partly paid by the government. However, at this moment, we could not yet retrieve these data, because it is unknown where they are, and whether they have been saved for future use. The costs of evacuation of all 200.000 people is very difficult to estimate, because about $98 \%$ of the people did not visit the evacuation centres, main did choose to visit friends and relatives all over the country. The government payed to each family 500 guilders (in total about 50 million guilders).

\section{Heavy rainfall in autumn 1998}

In September and October 1998 heavy rainfall caused a lot of water damage in the Netherlands. Due to constraints in the drainage of the polders and other water systems, much agricultural damage occurred. The average return period of the rainfall event was about 125 years. In the Netherlands there is a law which states the government can compensate the damages in case of cathostrophical events, such as heavy earthquakes. Because of this law, all damages has been estimated by damage-experts.

First estimates of the total damage looks as follows (note that not all data is complete). In total there has been a damage of about 900 million guilders, divided on the following categories: housing (10\%: 90 million guilders), agricultural companies: $85 \%$ (765 million guilders) and governmental agencies: (5\%: 45 million guilders). The total number of objects in the database is 14.700 (10.660 agricultural companies; 2.470 houses; 1.220 other companies; 350 governmental agencies).

The damage of all houses, industry, agriculture and the governmental buildings was estimated by damage-experts of the Dutch insurance companies.

\section{Discussion}

In this paper we described a database with the most important events with flood/water damage in the Netherlands. The data is directly linked with a geographic information system so that a spatial distribution of the damage is directly known. In this way the data can be linked with other data [7]. In our opinion it does make sense to extend the database with more (European) flood damage data, from all kind of floods. This 
extension is even more fruitful is the damage data can be linked to hydraulic and land use data. These data can be used to find better estimates of flood damage functions (which relate for example flood damage to inundation depths) and uncertainty distributions of flood damages [3].

\section{References}

1. Jorissen, R. (1996). Safety, Risk and Flood protection Policy. Ministry of Transport, Public Works and Water Management. Internal report.

2. Jorissen, R. and Kok, M. (1997) 'a physical-based approach to predicitng the frequency of extreme river waterlevel': review from problem owner and engineering perspective. In: Roger Cooke, Max Mendel and Han Vrijling, Engineering Prababilistic Design and Maintenance for Flood protection. Kluwer Academic Publishers, 1997.

3. Van Noortwijk, Jan M., Kok, M. and Cooke, R.M. (1996). Optimal decisions that reduce flood damage along the Meuse: an uncertainty analysis. In: S. French and J.Q. Smith (eds). The practice of Bayesian analysis, Arnold, London, 151-172..

4. Nierop, M. (1997). Schade in Kaart. Schadeanalyse van de Maasoverstromingen 1993 en 1995 in Limburg. MSc thesis, Universiteit Twente, 1997.

5. Delta Commission (1960). Report of the Delta Commission, The Hague, The Netherlands.

6. Van Danzig, D. (1956). Economic decision problems for flood protection. Econometrics, 276-287, New haven.

7. Hogeweg, M., Jonge, J. de, and Kok, M. (1996). Flood damage model of the river Meuse based on GIS. Proceedings of the fourth conferende on GIS, Vienna, 1996.

8. Delft Hydraulics (1994). Onderzoek Watersnood Maas. Deelrapport 1: wateroverlast 1993. Delft/De Voorst, 12 december 1994. 